\title{
Aktivitas Alanin Aminotransferase dan Aspartat Aminotransferase pada Broiler yang Diberikan Penambahan Tepung Temulawak dalam Pakan
}

\author{
(ACTIVITY OF ALANIN AMINOTRANSFERASE AND ASPARTAT AMINOTRANSFERASE \\ IN BROILER WITH ADDITION OF TEMULAWAK FLOUR IN FEED)
}

\section{Putu Diah Puspa Adhi, Ida Bagus Komang Ardana, Anak Agung Sagung Kendran}

Laboratorium Patologi Klinik Veteriner, Fakultas Kedokteran Hewan, Universitas Udayana, Jl. PB. Sudirman Denpasar-Bali. Email: diahpuspaadhi@ymail.com

\begin{abstract}
ABSTRAK
Temulawak (Curcuma xanthorrhiza Roxb.) merupakan salah satu tanaman obat yang banyak digunakan oleh masyarakat, termasuk digunakan secara luas pada hewan karena mempunyai banyak khasiat bagi kesehatan. Tujuan penelitian adalah untuk mengetahui efek penambahan tepung temulawak dalam pakan terhadap aktivitas ALT dan AST pada broiler. Penelitian ini menggunakan Rancangan Acak Lengkap (RAL) dengan 24 ekor broiler betina umur 14 hari yang dibagi menjadi 4 kelompok, yaitu kelompok P0 (pakan normal tanpa penambahan tepung temulawak), kelompok P1 (tepung temulawak $10 \mathrm{gr} / \mathrm{kg}$ pakan), P2 (tepung temulawak $20 \mathrm{gr} / \mathrm{kg}$ pakan), dan P3 (tepung temulawak $30 \mathrm{gr} / \mathrm{kg}$ pakan). Setelah umur 35 hari darah diambil melalui vena brachialis menggunakan spuit $5 \mathrm{ml}$ selanjutnya dilakukan pemeriksaan aktivitas ALT dan AST dengan menggunakan Photometer 5010. Data dianalisis dengan menggunakan Sidik Ragam/ANOVA. Hasil penelitian menunjukkan bahwa penambahan tepung temulawak dalam pakan broiler tidak mempengaruhi aktivitas ALT dan AST (P>0,05). Dari hasil penelitian dapat disimpulkan bahwa penambahan tepung temulawak dalam pakan broiler dosis $10 \mathrm{gr} / \mathrm{kg}$ pakan sampai $30 \mathrm{gr} / \mathrm{kg}$ pakan selama 21 hari masih tergolong dosis aman.
\end{abstract}

Kata kunci: Aktivitas; AST; ALT; broiler; temulawak.

\section{ABSTRACT}

Curcuma (Curcuma xanthorrhiza Roxb.) is one of the medicinal plants, which is widely used by the community, including used a lot in animals because it has many benefits for health. The purpose of this study is to find out the effect of the addition of curcuma flour on the feed toward the activity of ALT and AST on the broiler. This study used a Completely Randomized Design (CRD) with 24 female broilers aged 14 days which were divided into four groups, namely group P0 (normal feed without addition of curcuma flour), P1 group (curcuma flour 10gr/ $/ \mathrm{kg}$ of the feed)), P2 (curcuma flour $20 \mathrm{gr} / \mathrm{kg}$ of the feed)), and P3 (curcuma flour $30 \mathrm{gr} / \mathrm{kg}$ of the feed)). After 35 days, the blood is taken through the brachial vein using $5 \mathrm{ml}$ syringe. Then, the examination of ALT and AST activity is conducted by using Photometer 5010. The data were analyzed by using ANOVA. The results showed that the addition of curcuma flour in broiler's feed did not affect the activity of ALT and AST $(\mathrm{P}>0.05)$. From the study, it can be concluded that the addition of curcuma flour in broiler's feed the dose $10 \mathrm{gr} / \mathrm{kg}$ of feed until $30 \mathrm{gr} / \mathrm{kg}$ of feed for 21 days were still classified as safe dosage.

Keywords: AST; ALT; activities; broiler; temulawak.

\section{PENDAHULUAN}

Broiler adalah salah satu jenis ternak yang memberikan kontribusi cukup besar dalam memenuhi kebutuhan protein asal hewan masyarakat Indonesia. Untuk meningkatkan performan broiler para peternak biasa memberikan feed additive atau imbuhan pakan dalam bentuk obat sintetik. Penggunaan obat sintetik secara berlebihan akan menimbulkan gangguan keseimbangan atau ketidakstabilan mikroorganisme dalam saluran pencernaan. Larangan penggunaan antibiotik sebagai imbuhan pakan tertuang dalam Peraturan Menteri Pertanian Nomor 14/Permentan/PK.350/5/2017 tentang klasifikasi obat hewan. Bahaya penggunaan antibiotik pada budidaya 
hewan menjadi salah satu penyumbang timbulnya resistensi pada manusia (Amalia dan Adisasmito, 2017).

Dampak buruk dari penggunaan obat sintetik dapat dicegah, salah satu langkah yang dapat kita lakukan adalah mengganti obat sintetik yang biasa digunakan dengan obat herbal. Pada saat ini pengobatan herbal mulai diminati oleh masyarakat luas sebagai salah satu obat alternatif, karena obat herbal mengandung bahan alami yang dianggap bersifat lebih aman, lebih murah dibandingkan obat modern (Candra, 2013). Salah satu tanaman obat yang banyak dimanfaatkan adalah temulawak (Curcuma xanthorrhiza Roxb.)

Dewasa ini para peternak sering memberikan temulawak dengan tujuan untuk menjaga kesehatan broiler sehingga proses penyerapan makanan maksimal dan berat badan meningkat. Menurut Dian et al. (2014) temulawak yang diberikan pada unggas dapat meningkatkan nafsu makan ayam, menjaga kesehatan saluran pencernaan serta memacu pertumbuhan badan. Selain menjaga kesehatan saluran pencernaan, temulawak juga terbukti mampu menjaga kesehatan hati.

Organ hati merupakan organ yang kompleks yang berperan dalam proses detoksifikasi dan berfungsi sebagai sentral dalam metabolisme karbohidrat, lemak, dan protein (Giannini et al., 2005). Proses detoksifikasi dilakukan dengan cara mengubah semua bahan asing atau toksin menjadi bahan yang tidak membahayakan tubuh (Jupakan et al., 1993). Kemampuan hati mendetoksifikasi racun tergantung dari banyak dan lamanya toksin berada dalam tubuh. Apabila berlangsung lama dan dalam jumlah yang banyak akan merusak sel-sel hati. Kerusakan sel hati dapat diketahui dari struktur sel secara histopatologi atau dapat juga diketahui melalui indikator berupa substansi terkait dengan hati. Menurut Salam et al. (2014) aktivitas enzim ALT dan AST dapat digunakan sebagai indikator kerusakan selsel yang terdapat dalam hati akibat kerja hati yang semakin berat. Informasi tentang dosis penggunaan temulawak yang optimal untuk mampu berfungsi memelihara kesehatan hati broiler masih sangat terbatas. Oleh karena itu, penelitian ini dilakukan untuk mengetahui efek penambahan tepung temulawak dalam pakan terhadap kesehatan hati broiler.

\section{METODE PENELITIAN}

Sampel yang digunakan adalah sampel darah dari 24 ekor broiler betina umur 35 hari, dengan 4 perlakuan dan dengan 6 ulangan. Keempat perlakuan yang diberikan adalah: broiler yang hanya diberi pakan sebagai control (P0), broiler diberi pakan yang dicampur tepung temulawak sebanyak $10 \mathrm{gr} / \mathrm{kg}$ pakan (P1), broiler diberi pakan yang dicampur tepung temulawak sebanyak $20 \mathrm{gr} / \mathrm{kg}$ pakan (P2), broiler diberi pakan yang dicampur tepung temulawak sebanyak $30 \mathrm{gr} / \mathrm{kg}$ pakan (P3).

\section{Pengumpulan Data}

Data diperoleh dari hasil penghitungan ALT dan AST. Pemeriksaan dilakukan pada hari ke-21 setelah perlakuan. Darah diambil melalui vena brachialis. Darah kemudian dimasukkan dalam tabung berisi antikoagulan EDTA, lalu digoyangkan seperti membentuk angka delapan dengan tujuan agar antikoagulan tercampur merata. Setelah darah dimasukkan ke dalam tabung, kemudian darah disentrifuge. Pemeriksaan ALT dan AST dilakukan menggunakan alat penghitung aktivitas ALT dan AST yaitu Photometer 5010 (Irfan dan Esfandiari, 2016).

\section{Analisis Data}

Data yang diperoleh berupa aktivitas ALT dan AST, dianalisis dengan menggunakan Sidik Ragam/ANOVA (Sampurna dan Nindhia, 2008). Perhitungan ini dilakukan dengan menggunakan program statistik SPSS (Statistical Product and Service Solutions).

\section{HASIL DAN PEMBAHASAN}

Hasil pemeriksaan aktivitas ALT dan AST pada broiler yang diberikan penambahan tepung temulawak (Curcuma xanthorrhiza Roxb.) dalam pakan menunjukkan hasil pada tabel 1. 
Tabel 1. Rata-rata dan standar deviasi aktivitas ALT dan AST setelah pemberian tepung temulawak dalam pakan broiler.

\begin{tabular}{lrc}
\hline Perlakuan & ALT (U/L) & AST (U/L) \\
\hline P0 (Kontrol) & $28,17 \pm 9,196$ & $306,75 \pm 55,706$ \\
\hline P1 (10 g tepung temulawak/ kg pakan) & $33,75 \pm 8,704$ & $313,75 \pm 55,273$ \\
\hline P2 (20 g tepung temulawak/ kg pakan & $27,33 \pm 8,213$ & $335,67 \pm 59,550$ \\
\hline P3 (30 g tepung temulawak/ kg pakan) & $36,08 \pm 11,029$ & $308,83 \pm 88,612$ \\
\hline Rata-rata & $31,33 \pm 9,4959$ & $316,25 \pm 62,885$ \\
\hline
\end{tabular}

Hasil pemeriksaan aktivitas ALT dan AST broiler pada P0 yaitu sebagai kontrol adalah 28,17 U/L dan 306,75 U/L. Aktivitas ALT dan AST pada P1 yaitu broiler diberikan tepung temulawak dengan dosis $10 \mathrm{~g} / \mathrm{kg}$ pakan $(0,01 \mathrm{ppm})$ adalah 33,75 U/L dan 313,75 U/L. Aktivitas ALT dan AST pada P2 yaitu broiler diberikan tepung temulawak dengan dosis $20 \mathrm{~g} / \mathrm{kg}$ pakan (0,02 $\mathrm{ppm})$ adalah 27,33 U/L dan 335,67 U/L. Aktivitas ALT dan AST pada P3 yaitu broiler diberikan tepung temulawak dengan dosis $30 \mathrm{~g} / \mathrm{kg}$ pakan $(0,03 \mathrm{ppm})$ adalah 36,08 U/L dan 308,83 U/L. Berdasarkan hasil uji statistik, pemberian tepung temulawak tidak berpengaruh nyata $(\mathrm{P}>0,05)$ terhadap jumlah enzim ALT dan AST dalam darah broiler.

Tabel 2. Hasil Analisis Data Sidik Ragam (ANOVA) Aktivitas ALT

\begin{tabular}{cccccc}
\hline Source & $\begin{array}{c}\text { Type III Sum } \\
\text { of Squares }\end{array}$ & df & $\begin{array}{c}\text { Mean } \\
\text { Square }\end{array}$ & F & Sig. \\
\hline $\begin{array}{c}\text { Corrected } \\
\text { Model }\end{array}$ & $326.583^{\mathrm{a}}$ & 3 & 108.861 & 1.246 & 0.319 \\
\hline Intercept & 23562.667 & 1 & 23562.667 & 269.711 & 0.000 \\
\hline $\mathrm{P}$ & 326.583 & 3 & 108.861 & 1.246 & 0.319 \\
\hline Error & 1747.250 & 20 & 87.363 & & \\
\hline $\begin{array}{c}\text { Total } \\
\text { Corrected }\end{array}$ & 25636.500 & 24 & & & \\
\hline Total & 2073.833 & 23 & &
\end{tabular}

Tabel 3. Hasil Analisis Data Sidik Ragam (ANOVA) Aktivitas AST

\begin{tabular}{cccccc}
\hline Source & $\begin{array}{c}\text { Type III Sum } \\
\text { of Squares }\end{array}$ & df & $\begin{array}{c}\text { Mean } \\
\text { Square }\end{array}$ & F & Sig. \\
\hline $\begin{array}{c}\text { Corrected } \\
\text { Model }\end{array}$ & $3171.083^{\mathrm{a}}$ & 3 & 1057.028 & 0.241 & 0.867 \\
\hline Intercept & 2400337.500 & 1 & 2400337.500 & 546.874 & 0.000 \\
\hline $\mathrm{P}$ & 3171.083 & 3 & 1057.028 & 0.241 & 0.867 \\
\hline Error & 87783.917 & 20 & 4389.196 & & \\
\hline $\begin{array}{c}\text { Total } \\
\text { Corrected }\end{array}$ & 2491292.500 & 24 & & & \\
\hline Total & 90955.000 & 23 & &
\end{tabular}

Rataan aktivitas enzim ALT dan AST masing-masing sebesar 31,33 U/L dan 316,25 U/L. Rataan total enzim ALT dan
AST pada hasil penelitian ini lebih tinggi dibandingkan dengan aktivitas ALT dan AST pada penelitian yang dilakukan 
Darmawan et al. (2016) menggunakan onggok terfermentasi A. chorticola dan/atau antibiotik dalam ransum broiler yaitu rataan enzim ALT antara 13,18 - 19 U/L dan enzim AST antara 207,34 - 280, $06 \mathrm{U} / \mathrm{L}$. Meskipun lebih tinggi, namun aktivitas enzim ALT dan AST tidak berpengaruh nyata. Menurut Martani dan Murwani (2005) belum ada referensi mengenai aktivitas normal enzim ALT dan AST pada broiler.

Hati merupakan suatu organ yang memiliki peranan penting dalam metabolisme bahan toksik. Karena hati berfungsi dalam mendetoksifikasi senyawa-senyawa racun dan biotransformasi obat agar lebih mudah dikeluarkan dari tubuh (Tampubolon, 2014). Menurut BPOM RI (2005) temulawak memiliki manfaat memelihara kesehatan hati. Kurkumin yang terkandung dalam temulawak bekerja melindungi hati. Sukardi et al. (2010) telah menyatakan bahwa temulawak (Curcuma xanthorrhiza Roxb.) berkhasiat untuk menjaga kesehatan hati. Begitu pula dengan Rahardjo (2010) yang menyatakan bahwa dari uji praklinik temulawak dapat digunakan sebagai obat hepatoprotektor. Hewan sering memperoleh zat-zat bersifat toksik salah satunya dari imbuhan pakan yang diberikan sehingga menganggu kesehatan hati. Di dalam hati, temulawak mencegah hepatitis dan penyakit hati, membantu menurunkan kadar AST dan ALT, serta sebagai antihepatotoksik. Pernyataan tersebut didukung dengan penelitian Candra (2013) yang menyatakan temulawak mampu mencegah kenaikan jumlah ALT dan AST akibat pemberian parasetamol dosis toksik. Devaraj et al. (2010) dalam penelitiannya yang menggunakan hewan coba tikus menyatakan bahwa temulawak memiliki efek hepatoprotektor. Temulawak dapat menurunkan jumlah enzim ALT dan AST akibat pemberian alkohol.

Diperkuat oleh Hadi (2000) bahwa kurkumin pada temulawak mempunyai efek anti peradangan, antioksidan, antibakteri, hipolipidemik, hepatoprotektor. Namun, menurut Nirmala (2013) ekstrak temulawak yang digunakan dalam penelitian dengan menggunakan hewan coba mencit tidak memiliki efek hepatoprotektor. Hal tersebut dapat disebabkan karena jumlah temulawak yang digunakan kurang mencukupi dan kondisi temulawak yang berbeda seperti perbedaan masa tanam, tempat tumbuh dan jenis lahan penanaman.

\section{SIMPULAN DAN SARAN}

\section{Simpulan}

Berdasarkan hasil penelitian yang telah dilakukan dapat disimpulkan aktivitas ALT dan AST broiler tanpa diberikan tepung temulawak adalah $28,17 \mathrm{U} / \mathrm{L}$ dan 306,75 U/L. Aktivitas ALT dan AST broiler yang diberikan tepung temulawak dengan dosis $10 \mathrm{~g} / \mathrm{kg}$ pakan $(33,75 \mathrm{U} / \mathrm{L}$ dan $313,75 \mathrm{U} / \mathrm{L}), 20 \mathrm{~g} / \mathrm{kg}$ pakan $(27,33$ $\mathrm{U} / \mathrm{L}$ dan 335,67 U/L), dan $30 \mathrm{~g} / \mathrm{kg}$ pakan (36,08 U/L dan 308,83 U/L) tidak berpengaruh nyata $(p>0,05)$.

\section{Saran}

Pemberian tepung temulawak dengan dosis $10 \mathrm{~g} / \mathrm{kg}$ pakan, $20 \mathrm{~g} / \mathrm{kg}$ pakan, 30 $\mathrm{g} / \mathrm{kg}$ pakan terbukti tidak memberikan efek toksik terhadap hati sehingga aman untuk broiler.

\section{UCAPAN TERIMAKASIH}

Penulis mengucapkan terimakasih kepada UPT. Laboratorium Kesehatan Provinsi Bali dan Laboratorium Patologi Klinik Veteriner Fakultas Kedokteran Hewan Universitas Udayana yang telah membantu dan memfasilitasi penulis dalam penyelesaian penelitian ini.

\section{DAFTAR PUSTAKA}

Amalia Z, Adisasmito W. 2017. Analysis of policy making factors on the prohibition of hormones and antibiotics use for feed as a public health protection. J. Indonesian Health Policy and Administration. 2(2): 1419. 
BPOM RI (Badan Pengawas Obat dan Makanan Republik Indonesia). 2005. Gerakan Nasional Minum Temulawak. Info POM. 6(6): 1-12.

Candra AA. 2013. Aktivitas hepatoprotektor temulawak pada ayam yang diinduksi pemberian parasetamol. J Penelitian Pertanian Terapan. 13(2): 137-143.

Darmawan A, Putra FD, Isroli I, Sugiharto. 2016. Bobot hati, kadar SGOT dan SGPT pada ayam broiler yang diberi ransum menggunakan onggok terfermentasi acremonium chorticola dan/atau antibiotik. Seminar Nasional Program Studi Peternakan UNS.

Devaraj S, Ismail $S$, Ramanathan $S$, Marimuthu S, Mun Fei Y. 2010. Evaluation of the hepatoprotective activity of standardized ethanolic extract of curcuma xanthorrhiza roxb. J. Med. Plants Res. 4(23): 2512-2517.

Dian LMB, Sarayar CLK, Marie N, Utiah W. 2014. Efektivitas penambahan tepung temulawak dan tepung temu putih dalam ransum komersial terhadap performans ayam pedaging. J. Zootek. 34: 85-94.

Giannini EG, Testa R, Savarino V. 2005. Liver enzyme alterations: A guide forclinicians. Canadian Med. Asso. J. 172(3): 1497-1503.

Hadi S. 2000. Hepatologi. Bandung: Mandar Maju.

Irfan IZ, Esfandiari A. 2016. Aktivitas aspartate aminotransferase dan gamma glutamyltransferase pada sapi pejantan unggul. J. Ilmu Ternak. 16(1): 11-17.

Jupakan KVF, Kennedy PC, Peter C. 1993. Pathology of domestic animal. London: Academic Press. Pp. 325-346.

Martani HR, Murwani R. 2005. Aktivitas serum glutamat oksaloasetat transaminase dan serum glutamat piruvat transaminase broiler yang diberi ekstrak mengkudu (Morinda citrifolia) sebagai alternatif aditif klortetrasiklin. Proc. Seminar Nasional Fakultas Peternakan UGM Yogyakarta. Nirmala AZ. 2013. Perbedaan efek hepatoprotektif ekstrak etanolik kunyit, temulawak, dan kombinasinya pada mencit balb/c yang diinduksi parasetamol. Skripsi. Fakultas Kedokteran Universitas Sebelas Maret. Surakarta.

Rahardjo M. 2010. Penerapan SOP budidaya untuk mendukung temulawak sebagai bahan baku obat potensial. Perspektif. 9(2): 78-93.

Salam S, Sunarti D, Isroli. 2014. Pengaruh suplementasi jintan hitam (Nigella sativa) giling terhadap AST, ALT, dan berat organ hati broiler. J. Peternakan Indonesia. 16(1): 40-45.

Samarasinghe K, Wenk C, Silva KFST, Gunasekera JMDM. 2003. Turmeric root powder and manano ligo sacharides as alternative to antibiotic in broiler chicken diets. Asian-Aust. J. Anim. Sci. 16: 1495-1500.

Sampurn IP, Nindhia TS. 2008 Analisis data dengan SPSS dalam rancangan percobaan. Cetakan Pertama. Udayana University Press. Bali

Sukardi, Saptariyanti AKP, Taryana A. 2010. Analisis kelayakan industri tablet effervescent dari ekstrak temulawak (Curcuma xanthorrhiza Roxb.). J. Teknologi Pertanian. 10(8): 162-178.

Tampubolon SR, Ardana IBK, Sudira IW. 2014. Aktivitas alanine aminotransferase dan aspartat aminotransferase pada mencit yang diberikan jamu temulawak. Indonesia Medicus Veterinus. 3(3): 200-205. 